\title{
Baroreflex regulation affects ventilation in the cururu toad Rhinella schneideri
}

\author{
Lucas A. Zena ${ }^{1,2, *}$, Glauber S. F. da Silva ${ }^{1,2}$, Luciane H. Gargaglioni ${ }^{1,2}$ and Kênia C. Bícego ${ }^{1,2, *}$
}

\begin{abstract}
Anurans regulate short-term oscillations in blood pressure through changes in heart rate $\left(f_{\mathrm{H}}\right)$, vascular resistance and lymphatic $f_{\mathrm{H}}$. Lung ventilation in anurans is linked to blood volume homeostasis by facilitating lymph return to the cardiovascular system. We hypothesized that the arterial baroreflex modulates pulmonary ventilation in the cururu toad Rhinella schneideri, and that this relationship is temperature dependent. Pharmacologically induced hypotension (sodium nitroprusside) and hypertension (phenylephrine) increased ventilation $\left(25^{\circ} \mathrm{C}\right.$ : $248.7 \pm 25.7 \mathrm{ml} \mathrm{kg}^{-1} \mathrm{~min}^{-1}$; $35^{\circ} \mathrm{C}: 351.5 \pm$ $\left.50.2 \mathrm{ml} \mathrm{kg}^{-1} \mathrm{~min}^{-1}\right)$ and decreased ventilation $\left(25^{\circ} \mathrm{C}: 9.0 \pm\right.$ $6.6 \mathrm{ml} \mathrm{kg}^{-1} \mathrm{~min}^{-1}$; $35^{\circ} \mathrm{C}$ : $50.7 \pm 15.6 \mathrm{ml} \mathrm{kg}^{-1} \mathrm{~min}^{-1}$ ), respectively, relative to control values from Ringer solution injection $\left(25^{\circ} \mathrm{C}: 78.1 \pm\right.$ $17.0 \mathrm{ml} \mathrm{kg}^{-1} \mathrm{~min}^{-1} ; 35^{\circ} \mathrm{C}$ : $137.7 \pm 15.5 \mathrm{ml} \mathrm{kg}^{-1} \mathrm{~min}^{-1}$ ). The sensitivity of the ventilatory response to blood pressure changes was higher during hypotension than during hypertension $\left[25^{\circ} \mathrm{C}\right.$ : $-97.6 \pm 17.1$ versus $-23.6 \pm 6.0$ breaths $\mathrm{min}^{-1} \mathrm{kPa}^{-1} ; 35^{\circ} \mathrm{C}$ : $-141.0 \pm 29.5$ versus $-28.7 \pm 6.4$ breaths $\mathrm{min}^{-1} \mathrm{kPa}^{-1}$, respectively; negative values indicate an inverse relationship between blood pressure and ventilation (or breathing frequency), i.e. as blood pressure increases, ventilation decreases, and vice versa], while temperature had no effect on these sensitivities. Hyperoxia $\left(30 \% ; 25^{\circ} \mathrm{C}\right)$ diminished ventilation, but did not abolish the ventilatory response to hypotension, indicating a response independent of peripheral chemoreceptors. Although there are previous data showing increased $f_{\mathrm{H}}$ baroreflex sensitivity from 15 to $30^{\circ} \mathrm{C}$ in this species, further increases in temperature $\left(35^{\circ} \mathrm{C}\right)$ diminished $f_{\mathrm{H}}$ baroreflex gain $\left(40.5 \pm 5.62\right.$ versus $\left.21.6 \pm 4.64 \% \mathrm{kPa}^{-1}\right)$. Therefore, besides an involvement of pulmonary ventilation in matching $\mathrm{O}_{2}$ delivery to demand at higher temperatures in anurans, it also plays a role in blood pressure regulation, independent of temperature, possibly owing to an interaction between baroreflex and respiratory areas in the brain, as previously suggested for mammals.
\end{abstract}

KEY WORDS: Baroreceptors, Chemoreceptors, Lung ventilation, Hyperoxia, Autonomic blockade, Anuran amphibians

\section{INTRODUCTION}

Across vertebrates, the negative feedback mechanisms that drive short-term blood pressure regulation rely on mechanoreceptors (baroreceptors) located on the wall of the arterial system that detect fluctuations in blood pressure. The afferent baroreceptor

${ }^{1}$ Department of Animal Morphology and Physiology, College of Agricultural and Veterinary Sciences, São Paulo State University, Jaboticabal, São Paulo 14884 900, Brazil. ${ }^{2}$ National Institute of Science and Technology in Comparative Physiology (INCT Fisiologia Comparada), Jaboticabal, São Paulo 14884-900, Brazil.

*Authors for correspondence (lucaszena@yahoo.com.br; keniacb@fcav.unesp.br)

(D) L.A.Z., 0000-0002-4422-4458

Received 17 June 2016; Accepted 31 August 2016 information is then relayed to and integrated in the central nervous system (CNS), where baroreflex buffering capacity is achieved by reflexively altering heart rate $\left(f_{\mathrm{H}}\right)$ and vascular resistance (Altimiras et al., 1998; Bianchi-da-Silva et al., 2000; Sandblom and Axelsson, 2005; Hedrick et al., 2015; Zena et al., 2015, 2016). Besides cardiovascular responses, the baroreflex also influences respiratory function in mammals (for a review, see McMullan and Pilowsky, 2010). Although there are some suggestive data for baroreflex modulation of the respiratory system in crocodilians and amphibians (Van Vliet and West, 1986; Altimiras et al., 1998; Hedrick et al., 2013), there is still no direct evidence of a respiratory component in the reflex regulation of blood pressure in non-mammalian vertebrates.

Amphibians' cardiorespiratory homeostatic mechanisms for monitoring blood pressure and blood gases involve sensory information from baroreceptors and chemoreceptors, respectively, located in their major arterial vessels: the pulmocutaneous artery, the carotid artery and the aortic arch (Bianchi-da-Silva et al., 2000; Reyes et al., 2014). While the identity of these receptors has already been described, their relative contributions to cardiorespiratory control remain under investigation. Arterial partial pressure of oxygen homeostasis is maintained by peripheral chemoreceptor regulation of breathing (Wang et al., 1994; Branco and Glass, 1995), whereas regulation of blood pressure by arterial baroreceptors is adjusted by changing vascular resistance and cardiac frequency. Furthermore, anurans possess lymph hearts (pulsatile organs), which are under baroreflex control, that function to pump lymph into the venous system (Crossley and Hillman, 1999).

Besides their role in gas exchange, amphibian lungs are associated with some ecophysiological functions including vocalization, buoyancy and defensive behavior (Hillman et al., 2009; Jared et al., 2009). In addition, lung ventilation has been directly linked to vertical lymph mobilization and, hence, blood volume homeostasis (Hedrick et al., 2007; Hillman et al., 2010). By transmitting pressure and volume changes to the surrounding lymph sacs, pulmonary ventilation in anuran amphibians facilitates lymph movement against gravitational forces towards dorsally located lymph hearts, thereby preventing lymph accumulation (Hedrick et al., 2013). As a component of the lymphatic system in anurans, dorsally located anterior and posterior lymphatic hearts participate in blood volume regulation by pumping lymphatic fluid generated by an increased net transcapillary flux back into the venous system (Crossley and Hillman, 1999). This is evident from the cane toad (Rhinella marina), which has an extraordinary ability to acutely compensate for high blood losses $(78 \%$ of their initial blood volume), but destruction of both anterior and posterior lymph hearts critically impairs this ability, leading to hemoconcentration and death in few days (Baustian, 1988).

The cururu toad Rhinella schneideri is a widespread bufonid with a broad distribution in natural habitats in South America (Chaco, savanna-like Cerrado, and Atlantic Forest), and is also found in open 


$\begin{array}{ll}\text { List of symbols and abbreviations } \\ \mathrm{CNS} & \text { central nervous system } \\ f_{\mathrm{H}} & \text { heart rate } \\ \mathrm{Fl}_{\mathrm{O}_{2}} & \text { fraction of oxygen in the inspired air } \\ f_{\mathrm{R}} & \text { breathing frequency } \\ \mathrm{Pa}_{\mathrm{O}_{2}} & \text { arterial partial pressure of oxygen } \\ \mathrm{PAP} & \text { pulsatile arterial pressure } \\ \mathrm{PE} & \text { phenylephrine } \\ P_{\mathrm{MA}} & \text { mean arterial blood pressure } \\ \mathrm{SNP} & \text { sodium nitroprusside } \\ \dot{V}_{\mathrm{E}} & \text { total ventilation } \\ V_{\mathrm{T}} & \text { tidal volume }\end{array}$

and urban areas. Despite daily maximum air temperatures reaching over $35^{\circ} \mathrm{C}$ during the summer season in southeastern Brazil (CIIAGRO: $\mathrm{http}: / / w w w . c i i a g r o . s p . g o v \cdot b r / c i i a g r o o n l i n e /)$, experiments have shown a preferred body temperature of around $23-27^{\circ} \mathrm{C}$ for this species (Bícego-Nahas et al., 2001; Guerra et al., 2008; Noronha-de-Souza et al., 2015). Therefore, in order to avoid potential damage due to extreme ambient temperatures, amphibians would seek places that maintain a more moderate humidity and temperature (Moreira et al., 2009; Noronha-de-Souza et al., 2015).

Based on the roles played by lung ventilation in blood volume homeostasis in anurans (Crossley and Hillman, 1999; Hedrick et al., 2007; Hillman et al., 2010, 2013) and in $\mathrm{O}_{2}$ delivery to match metabolic demands, we tested the hypothesis that pulmonary ventilation contributes to the baroreflex responses to blood pressure imbalances in $R$. schneideri, and that this effect is modulated by changes in temperature. To this end, baroreflex function was assessed through pharmacological interventions on arterial blood pressure, i.e. the Oxford method, at 25 and $35^{\circ} \mathrm{C}$. Heart rate buffering reflex responses were evaluated along with ventilation, breathing frequency and tidal volume. Considering that anuran peripheral chemoreceptors mainly adjust ventilation in response to changes in the partial pressure of arterial oxygen (Branco and Glass, 1995; Wang et al., 1994), toads were exposed to hyperoxia [ fraction of oxygen in the inspired air $\left.\left(F_{\mathrm{I}_{2}}\right)=0.30\right]$ to account for possible influences of peripheral chemoreceptors on the ventilatory response during hypotension at $25^{\circ} \mathrm{C}$. Furthermore, ventilatory responses to hypotension were also tested after total autonomic blockade.

\section{MATERIALS AND METHODS}

\section{Animals}

Cururu toads Rhinella schneideri (Werner 1894), of both sexes (159.5 $\pm 7.7 \mathrm{~g}$ body mass), were collected in swampy areas in the Ribeirão Preto region of São Paulo State, Brazil (approximately $21^{\circ} 10^{\prime} \mathrm{S}$ and $47^{\circ} 48^{\prime} \mathrm{W}$ ), and transported to our laboratory at the Department of Animal Morphology and Physiology, UNESP, Jaboticabal, Brazil (approximately $21^{\circ} 14^{\prime} \mathrm{S}$ and $48^{\circ} 17^{\prime} \mathrm{W}$ ). All animals were maintained at $25^{\circ} \mathrm{C}$ on a $12 \mathrm{~h}: 12 \mathrm{~h}$ light:dark cycle with free access to water from an artesian well and a basking area. They were housed in containers with coconut fiber as a substrate and tubes for hiding in, and were held under laboratory conditions for at least 3 weeks before experimentation. Animals were fed 2-3 times a week with captive-bred speckled cockroaches (Nauphoeta cinerea), which were dusted with calcium and vitamin $\mathrm{D}_{3}$. All experiments were performed from September to March, which matches the activity season of this species (Bícego-Nahas et al., 2001; Glass et al., 1997). Animal collection was approved by the Brazilian environmental agency (SISBIO-ICMBio/no. 35484-1), and the study was conducted with the approval of our Institutional Animal
Care and Use Committee (CEUA-FCAV-UNESP; protocol no. 017204/12).

\section{Surgical procedures}

Procedures were performed as previously described (Zena et al., 2015). Briefly, anesthesia was performed through immersion in an aqueous $0.25 \%$ solution of 3-aminobenzoic acid ethyl ester (MS222; Sigma, St Louis, MO, USA), buffered to $\mathrm{pH} 7.7$ with sodium bicarbonate, for $10 \mathrm{~min}$ or more until animals lost the palpebral reflex. A polyethylene cannula (PE-50; Clay Adams, Parsippany, NJ, USA), filled with heparinized Ringer solution (100 i.u. $\mathrm{ml}^{-1}$ heparin) was occlusively inserted into the iliac artery and sutured in place. The same procedure was used to cannulate the femoral vein (100 i.u. $\mathrm{ml}^{-1}$ heparin in Ringer solution) for drug injections. Just after surgery, toads were treated with a prophylactic antibiotic (enrofloxacin, Flotril ${ }^{\circledR}, 5.0 \mathrm{mg} \mathrm{kg}^{-1}$ s.c.; Schering-Plough) and an analgesic (flunixina meglumina, Banamine ${ }^{\circledR}, 1.0 \mathrm{mg} \mathrm{kg}^{-1}$ s.c.; Schering-Plough) (Gentz, 2007; Smith, 2007). Each animal was then individually placed in a temperature-controlled chamber at $25^{\circ} \mathrm{C}$ in the experimental room, where it was allowed to recover for a minimum of $48 \mathrm{~h}$ without disturbance before the experimental procedure was begun.

\section{Drugs}

Phenylephrine hydrochloride (PE, agonist of $\alpha 1$-adrenergic receptors), sodium nitroprusside dihydrate (SNP, nitric oxide donor), atropine sulfate (antagonist of muscarinic receptors) and sotalol hydrochloride (antagonist of $\beta$-adrenergic receptors) were purchased from Sigma. All drugs were dissolved in amphibian Ringer solution (mmol 1-1: $46.9 \mathrm{NaCl}, 21.0 \mathrm{KCl}, 2.40 \mathrm{CaCl}, 1.29$ $\left.\mathrm{MgCl}, 3.14 \mathrm{NaHCO}_{3}\right)$.

\section{Ventilation and arterial blood pressure measurements}

Pulmonary ventilation $\left(\dot{V}_{\mathrm{E}}\right)$, tidal volume $\left(V_{\mathrm{T}}\right)$ and breathing frequency $\left(f_{\mathrm{R}}\right)$ were calculated from the recordings of breathing using the pneumotachography method described by Glass et al. (1978). A facemask was built for each toad from $1.0 \mathrm{~mm}$-thick silicon sheets (Bio-Art Equipamentos Odontológicos, São Carlos, Brazil) heat-molded on a plaster cast of the toad's head. The pneumotachograph was attached to the mask and subsequently fixed to the animal's snout (see below), allowing airflow to be measured continuously. A direct relationship exists between laminar airflow and the pressure difference across this tube, which was monitored with a differential pressure transducer (MLT141Spirometer, PowerLab System, ADInstruments) connected to a data acquisition system that included specific application software (PowerLab System, ADInstruments/Chart Software, v7.3, Sydney, Australia). Calibrations were performed for each mask by injecting 1, 3 and $5 \mathrm{ml}$ volumes of air through the pneumotachograph using a graduated syringe. The arterial cannulae were connected to a physiological pressure transducer (MLT844, ADInstruments), calibrated against a mercury column. The transducer was connected to a data acquisition system (PowerLab System, ADInstruments/Chart Software, v7.3) via a bridge amplifier (FE221, ADInstruments). $f_{\mathrm{H}}$ and mean arterial blood pressure $\left(P_{\mathrm{MA}}\right)$ were calculated from the pulsatile arterial pressure (PAP) recorded in real-time using the cyclic measurements tool from the Chart Software.

\section{Experimental protocol}

Toads were housed in an acrylic water-jacketed chamber kept at the experimental temperature of $25^{\circ} \mathrm{C}$ using a constant-temperature 
circulating water bath (PolyScience 9112A11B programmable model 9112 refrigerated circulator). A facemask attached to the pneumotachograph was glued to the animal's snout using a polyether impression material (Impregum Soft, 3M ESPE, St Paul, MN, USA) $24 \mathrm{~h}$ after surgery. Experiments began $48 \mathrm{~h}$ after surgery and $24 \mathrm{~h}$ after facemask attachment. For experiments at high temperature, the toads were acclimated to $35^{\circ} \mathrm{C}$ for at least $6 \mathrm{~h}$, beginning $48 \mathrm{~h}$ after surgery. The experimental chamber was continuously flushed with humidified room air, and the temperature inside was continuously measured using a temperature sensor (MLT415/M thermistor temperature sensor, ADInstruments). After 60 min of basal recordings of $f_{\mathrm{H}}$, blood pressure and ventilation airflow, Ringer solution $\left(0.4 \mathrm{ml} \mathrm{kg}^{-1}\right)$ was injected into the femoral vein in order to verify any influence of volume injection on all variables subsequently evaluated. Serial intravenous injections of increasing doses of PE and SNP were then performed (doses are given in 'Analysis and assessment of the baroreflex', below). All cardiorespiratory parameters were recorded throughout the experimental protocol. Between drug injections, cardiorespiratory parameters were always allowed to return to similar pre-injection values.

Five animals from the main experimental group described above had full autonomic blockade at $25^{\circ} \mathrm{C}$, which was performed on the day after the baroreflex experiment. It consisted of injections of the $\beta$-adrenergic receptor antagonist sotalol $\left(3.0 \mu \mathrm{g} \mathrm{kg}^{-1}\right)$ and of the muscarinic receptor antagonist atropine $\left(3.0 \mu \mathrm{g} \mathrm{kg}^{-1}\right)$. Cardiorespiratory variables were recorded continuously in animals injected with SNP $\left(100 \mu \mathrm{g} \mathrm{kg}^{-1}\right)$ before and after full autonomic blockade.

Five additional animals were subjected to hyperoxia $\left(F_{\mathrm{I}_{\mathrm{O}_{2}}}=0.30\right)$ to identify any possible involvement of the peripheral chemoreceptors in the respiratory responses to blood pressure adjustments. For hyperoxia experiments, following the baroreflex protocol, animals were exposed to $30 \% \mathrm{O}_{2}$ for at least $30 \mathrm{~min}$. After this interval, $100 \mu \mathrm{g} \mathrm{kg}^{-1} \mathrm{SNP}$ injection was repeated in order to identify respiratory responses under hypotension in the hyperoxic condition.

\section{Analysis and assessment of the baroreflex}

Reflex responses of $f_{\mathrm{H}}$ were evaluated by altering blood pressure through serial injections of increasing doses of PE $(5,10,25,50$ and $100 \mu \mathrm{g} \mathrm{kg}^{-1}$; eliciting blood pressure increases) and SNP (5, $10,25,50$ and $100 \mu \mathrm{g} \mathrm{kg}^{-1}$; eliciting blood pressure decreases) at both 25 and $35^{\circ} \mathrm{C} . f_{\mathrm{H}}$ was plotted against $P_{\mathrm{MA}}(\mathrm{kPa})$ data obtained for each animal at each temperature and fitted to a four-variable sigmoidal logistic function as described previously by Reid (1996):

$$
f_{\mathrm{H}}=\frac{(A-D)}{1+\left(P_{\mathrm{MA}} / C\right)^{B}}+D,
$$

where $A$ is maximum $f_{\mathrm{H}}$ and $D$ is minimum $f_{\mathrm{H}}\left(\right.$ beats $\left.\min ^{-1}\right)$ of the curve, $B$ is the slope coefficient (beats $\mathrm{min}^{-1} \mathrm{kPa}^{-1}$ ) and $C$ is the $P_{\mathrm{MA}}$ at the midpoint of the $f_{\mathrm{H}}$ range $\left(P_{\mathrm{MA}, 50} ; \mathrm{kPa}\right)$. The range of the baroreflex was calculated as the difference between $A$ and $D$. The maximum gain of the curve $\left(G_{50}\right.$; beats $\left.\mathrm{min}^{-1} \mathrm{kPa}^{-1}\right)$, which occurs when $P_{\mathrm{MA}}$ equals $C$, was determined by taking the first derivative of Eqn 1, resulting in the gain equation:

$$
G_{50}=\frac{-B(A-D)}{4 C} .
$$

To allow meaningful comparisons between temperatures, the maximal gain was normalized as a percentage change in $f_{\mathrm{H}}$ per unit
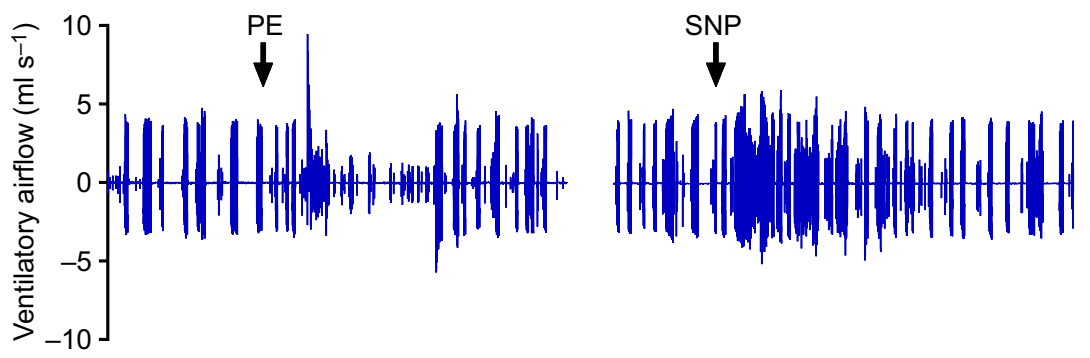

Fig. 1. Ventilatory airflow, pulsatile arterial blood pressure (PAP) and heart rate $\left(f_{\mathrm{H}}\right)$ of the cururu toad Rhinella schneideri at $25^{\circ} \mathrm{C}$. Original traces from one toad. The arrows indicate the time of intravenous injection of phenylephrine (PE; $50.0 \mathrm{\mu g} \mathrm{kg}^{-1}$ ) and sodium nitroprusside (SNP; $50.0 \mu \mathrm{g} \mathrm{kg}^{-1}$ ). The black line in the PAP signal represents mean arterial blood pressure $\left(P_{\mathrm{MA}}\right)$.
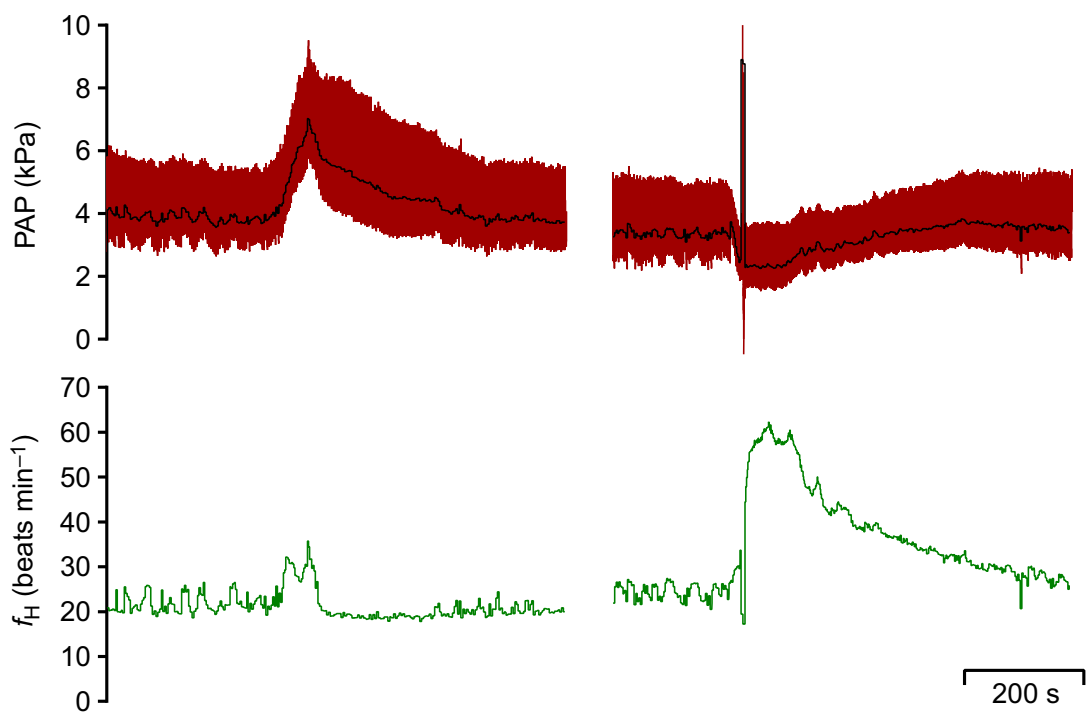

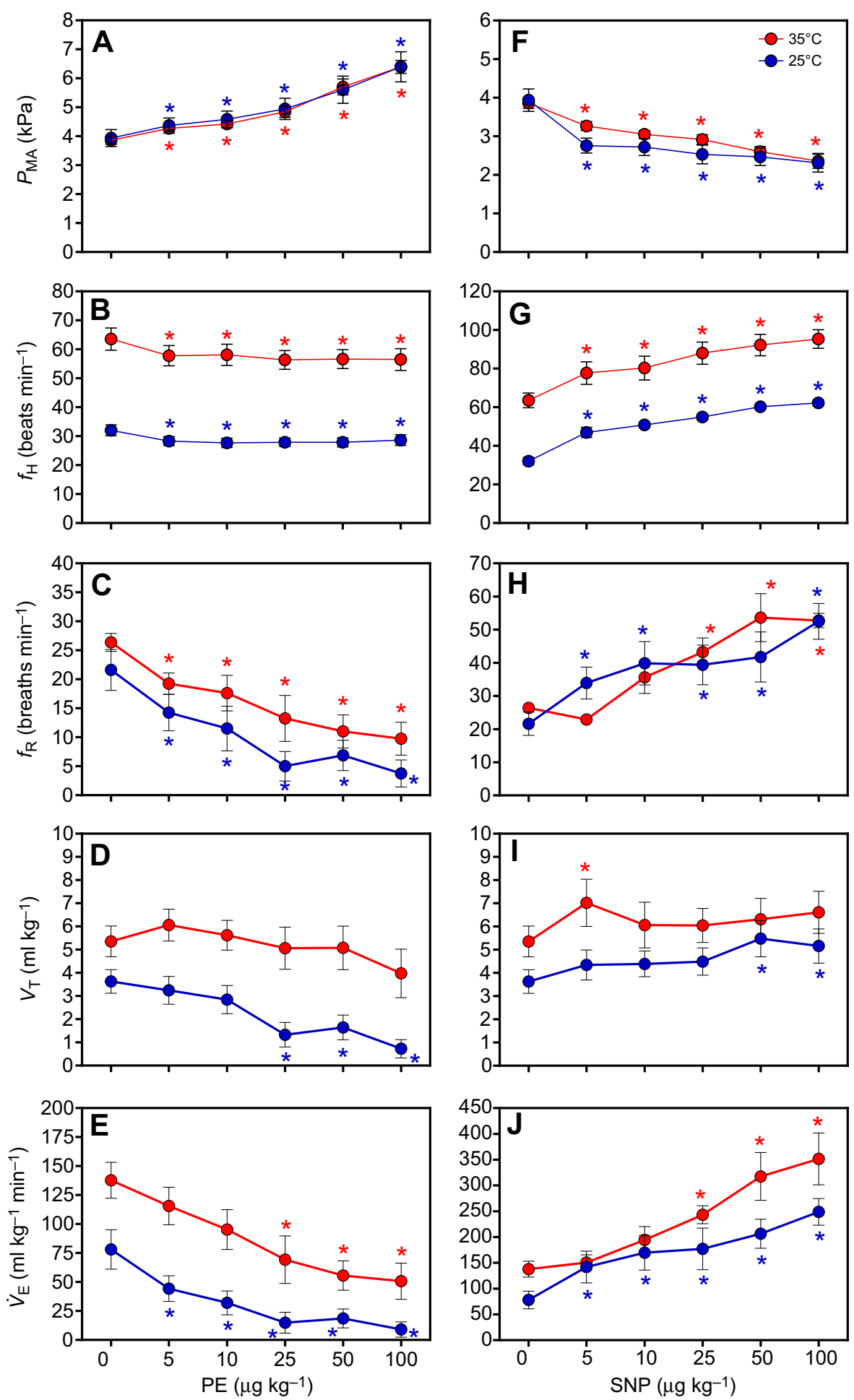

Fig. 2. Effect of pharmacological manipulations on $P_{\mathrm{MA}}, f_{\mathrm{H}}$, breathing frequency $\left(f_{\mathrm{R}}\right)$, tidal volume $\left(V_{\mathrm{T}}\right)$ and ventilation $\left(\dot{V}_{\mathrm{E}}\right)$ in $R$. schneideri at 25 and $35^{\circ} \mathrm{C}$. Data are for intravenous injection of Ringer solution and serially increasing doses of $\mathrm{PE}$ $(\mathrm{A}-\mathrm{E})$ and SNP $(\mathrm{F}-\mathrm{J})$ at 25 and $35^{\circ} \mathrm{C}$. Blue asterisks indicate a significant effect of drugs relative to Ringer solution at $25^{\circ} \mathrm{C}$; red asterisks indicate a significant effect of drugs relative to Ringer solution at $35^{\circ} \mathrm{C}$ (two-way repeated measures ANOVA; $P<0.05$; Holm-Š́dák's post hoc test). Cardiovascular parameters, $N=9$; ventilatory parameters, $N=8$. change in $P_{\mathrm{MA}}\left(\% \mathrm{kPa}^{-1}\right)$ relative to the minimum heart rate $(D)$, as described by Altimiras et al. (1998):

$$
G=\frac{100 B}{D}
$$

\section{Data analysis and statistics}

Data are shown as means \pm s.e.m. The effect of temperature on baseline cardiorespiratory and baroreflex variables was analyzed through a Student $t$-test and Mann-Whitney $U$-test for parametric and non-parametric data, respectively. The effects of Ringer solution and serial bolus injection of PE and SNP on $P_{\mathrm{MA}}, f_{\mathrm{H}}, f_{\mathrm{R}}$, $V_{\mathrm{T}}$ and $\dot{V}_{\mathrm{E}}$ at 25 and $35^{\circ} \mathrm{C}$ were analyzed using a two-way repeatedmeasures ANOVA (factors: drugs and temperature). Different $F_{\mathrm{I}_{\mathrm{O}_{2}}}(0.21$ and 0.30$)$ before and after SNP-induced hypotension for $\dot{V}_{\mathrm{E}}$ and the effect of full autonomic blockade on hypotension induced by SNP were analyzed through two-way repeated-measures ANOVA. Regression analyses were used to evaluate temperature influences on $f_{\mathrm{R}} / P_{\mathrm{MA}}$ and $V_{\mathrm{E}} / P_{\mathrm{MA}}$ relationships during hypotension and hypertension stimuli and a two-way ANOVA was used to 
Table 1. Baseline cardiorespiratory and baroreflex variables derived from sigmoidal baroreflex-heart rate curves generated after serial bolus injections of phenylephrine and sodium nitroprusside (Eqn 1) at 25 and $35^{\circ} \mathrm{C}$ in the toad Rhinella schneideri

\begin{tabular}{|c|c|c|c|}
\hline & $25^{\circ} \mathrm{C}$ & $35^{\circ} \mathrm{C}$ & $P$ \\
\hline \multicolumn{4}{|l|}{ Baseline variables } \\
\hline$P_{\mathrm{MA}}(\mathrm{kPa})$ & $3.95 \pm 0.31$ & $3.83 \pm 0.15$ & 0.73 \\
\hline$f_{\mathrm{H}}$ (beats $\left.\min ^{-1}\right)$ & $32.2 \pm 1.83$ & $64.3 \pm 3.69$ & $<0.001^{*}$ \\
\hline$\dot{V}_{\mathrm{E}}\left(\mathrm{ml} \mathrm{kg}{ }^{-1} \mathrm{~min}^{-1}\right)$ & $62.0 \pm 11.5$ & $143.3 \pm 15.9$ & $0.001^{*}$ \\
\hline$V_{\mathrm{T}}\left(\mathrm{ml} \mathrm{kg}{ }^{-1}\right)$ & $3.80 \pm 0.53$ & $5.79 \pm 0.68$ & $0.037^{*}$ \\
\hline$f_{\mathrm{R}}$ (breaths $\min ^{-1}$ ) & $18.3 \pm 3.95$ & $25.2 \pm 1.96$ & 0.14 \\
\hline \multicolumn{4}{|l|}{ Baroreflex variables } \\
\hline Minimum $f_{\mathrm{H}}$ (beats $\min ^{-1}$ ) & $27.0 \pm 1.61$ & $54.5 \pm 3.47$ & $<0.001^{*}$ \\
\hline Maximum $f_{\mathrm{H}}$ (beats $\min ^{-1}$ ) & $62.3 \pm 1.45$ & $96.1 \pm 4.94$ & $<0.001^{*}$ \\
\hline$f_{\mathrm{H}}$ range (beats $\min ^{-1}$ ) & $35.3 \pm 2.74$ & $41.6 \pm 3.48$ & 0.17 \\
\hline$R^{2}$ & $0.93 \pm 0.01$ & $0.94 \pm 0.02$ & 0.48 \\
\hline Slope coefficient & $10.9 \pm 1.62$ & $11.3 \pm 2.02$ & 0.93 \\
\hline$P_{\mathrm{MA}, 50}(\mathrm{kPa})$ & $3.10 \pm 0.21$ & $3.32 \pm 0.09$ & 0.38 \\
\hline $\mathrm{G}_{50}\left(\right.$ beats $\left.\min ^{-1} \mathrm{kPa}^{-1}\right)$ & $30.8 \pm 4.49$ & $38.3 \pm 9.80$ & 1.00 \\
\hline Normalized gain $\left(\% \mathrm{kPa}^{-1}\right)$ & $40.5 \pm 5.62$ & $21.6 \pm 4.64$ & $0.017^{*}$ \\
\hline
\end{tabular}

$P_{\mathrm{MA}}$, mean arterial blood pressure; $f_{\mathrm{H}}$, heart rate; $\dot{V}_{\mathrm{E}}$, ventilation; $V_{\mathrm{T}}$, tidal volume; $f_{\mathrm{R}}$, breathing frequency; $R^{2}$, coefficient of determination; slope coefficient, slope of the linear portion of the curve; $P_{\mathrm{MA}, 50}$, mean arterial blood pressure at the midpoint of the curve; $G_{50}$, maximum gain .

Data are expressed as means \pm s.e.m. Cardiovascular and baroreflex parameters, $N=9$; ventilatory parameters, $N=8$

*Significant difference between temperatures.

compare slopes (pressure and temperature). In addition, the relationship between $P_{\mathrm{MA}}$ and ventilatory responses $\left(f_{\mathrm{R}}, V_{\mathrm{T}}\right.$ and $\dot{V}_{\mathrm{E}}$ ) was binned into $P_{\mathrm{MA}}$ categories in order to evaluate the influence of temperature in those relationships (two-way ANOVA; pressure and temperature). In all ANOVA analyses, the differences among means were further assessed by Holm-Sídák post hoc tests and were considered significant when $P<0.05$. Data were tested for unequal variance and normality, and when necessary appropriate transformations were performed.

\section{RESULTS}

Mean baseline cardiorespiratory variables for toads at 25 and $35^{\circ} \mathrm{C}$ are shown in Table 1. No significant temperature effect on $P_{\mathrm{MA}}$ was observed $(P=0.73)$, whereas $f_{\mathrm{H}}$ was significantly elevated at $35^{\circ} \mathrm{C}$ $(P<0.001)$. Temperature significantly augmented resting $\dot{V}_{\mathrm{E}}$ $(P=0.001)$ in toads, mainly by increases in $V_{\mathrm{T}}(P=0.037)$.

An original PAP trace of one toad at $25^{\circ} \mathrm{C}$ exhibiting a typical tachycardic reflex response to a reduction in $P_{\mathrm{MA}}$ after injection of SNP $\left(50 \mu \mathrm{g} \mathrm{kg}^{-1}\right)$ is shown in Fig. 1. In addition, a parallel increase in ventilatory airflow was observed during hypotension. In contrast, the increase in $P_{\mathrm{MA}}$ after a bolus injection of PE $\left(50 \mu \mathrm{g} \mathrm{kg}^{-1}\right)$ had a very small effect on $f_{\mathrm{H}}$ (small bradycardia) besides the diminished ventilatory airflow.

\section{Effect of temperature on the blood pressure influence on cardiorespiratory variables}

Serial injections of increasing doses of PE elevated $P_{\mathrm{MA}}$ (effect of treatment: $P<0.001 ; F_{5,102}=90.141$; Fig. 2 A) and evoked a small decrease in $f_{\mathrm{H}}$ (effect of treatment: $P<0.001 ; F_{5,102}=20.049$; Fig. 2B) at both temperatures tested, while temperature had significant effects on $f_{\mathrm{H}}$ (effect of temperature: $P<0.001$; $F_{1,106}=59.548$; Fig. 2B), but not on $P_{\mathrm{MA}}$ (Fig. 2A). Along with reflexive effects on $f_{\mathrm{H}}$, PE-induced hypertension caused a significant decrease in $f_{\mathrm{R}}$ independent of temperature (effect of treatment: $P<0.001 ; F_{5,90}=21.137$; Fig. 2 C). In contrast, $V_{\mathrm{T}}$ was significantly reduced by injections of 25,50 and $100 \mu \mathrm{g} \mathrm{kg}^{-1} \mathrm{PE}$ at $25^{\circ} \mathrm{C}$ only (effect of treatment: $P<0.001 ; F_{5,90}=5.951$; Fig. 2D). When temperature was increased to $35^{\circ} \mathrm{C}, V_{\mathrm{T}}$ remained unchanged for all doses of $\mathrm{PE}$ that induced hypertension, but was elevated relative to values at $25^{\circ} \mathrm{C}$ (effect of temperature: $P<0.001$; $F_{1,94}=19.565$; Fig. 2D). Overall, increasing $P_{\mathrm{MA}}$ evoked parallel reductions in $\dot{V}_{\mathrm{E}}$ independent of temperature (effect of treatment: $P<0.001 ; F_{5,90}=17.783$; Fig. $2 \mathrm{E}$ ), mainly due to decreases in $f_{\mathrm{R}}$. Because $V_{\mathrm{T}}$ was unaffected by hypertension at $35^{\circ} \mathrm{C}, \dot{V}_{\mathrm{E}}$ values were maintained elevated at $35^{\circ} \mathrm{C}$ relative to those at $25^{\circ} \mathrm{C}$ (effect of temperature: $P=0.002 ; F_{1,94}=13.858$; Fig. $2 \mathrm{E}$ ).

In contrast to $P E$ effects, serial injections of increasing doses of SNP decreased $P_{\mathrm{MA}}$ (interaction of temperature $\times$ treatment: $P=0.028$; $F_{5,102}=2.671$; Fig. $2 \mathrm{~F}$ ), causing a pronounced reflex increase in $f_{\mathrm{H}}$ (interaction of temperature $\times$ treatment: $P=0.049 ; \quad F_{5,102}=2.343$; Fig. 2G). In addition, because high temperature significantly shifted baseline $f_{\mathrm{H}}$ to higher values (see Table 1), reflex tachycardia was also maintained elevated across all SNP-induced hypotension doses relative to $25^{\circ} \mathrm{C}$ (effect of temperature: $P<0.001 ; F_{1,106}=73.105$; Fig. 2G). Reductions of $P_{\mathrm{MA}}$ induced increases in $f_{\mathrm{R}}$ (effect of treatment: $P<0.001 ; F_{5,90}=16.858$; Fig. $\left.2 \mathrm{H}\right)$ that were followed by increases in $V_{\mathrm{T}}$ at higher doses of SNP at $25^{\circ} \mathrm{C}$, while SNP-induced hypotension evoked an increase in $V_{\mathrm{T}}$ at the lowest SNP dose at $35^{\circ} \mathrm{C}$ only (effect of treatment: $P=0.002 ; F_{5,90}=4.398$; Fig. 2I). Thus, regardless of temperature, SNP-induced hypotension effects on $V_{\mathrm{T}}$ and $f_{\mathrm{R}}$ in $R$. schneideri resulted in a significant increase in total ventilation (effect of treatment: $P<0.001 ; F_{5,90}=24.656$; Fig. $2 \mathrm{~J}$ ).

\section{Effect of temperature on the relationship between $\boldsymbol{P}_{\mathrm{MA}}, \boldsymbol{f}_{\mathrm{H}}$ and $\dot{V}_{E}$}

Increasing the temperature from 25 to $35^{\circ} \mathrm{C}$ resulted in an upward shift in the relationship between $P_{\mathrm{MA}}$ and $f_{\mathrm{H}}$ (Fig. 3). The operating point (represented by baseline $P_{\mathrm{MA}}$ and $f_{\mathrm{H}}$ values) in this relationship was moved up mainly because of temperature effects on baseline $f_{\mathrm{H}}(P<0.001$; Table 1 and Fig. 3). Despite a $10^{\circ} \mathrm{C}$ increment in temperature, the $f_{\mathrm{H}}$ baroreflex was not enhanced, as can be observed by similarities between absolute gain at 25 and $35^{\circ} \mathrm{C}(P=1.0$; Table 1$)$. Because of the significant effect of temperature on resting $f_{\mathrm{H}}$, absolute gain was then

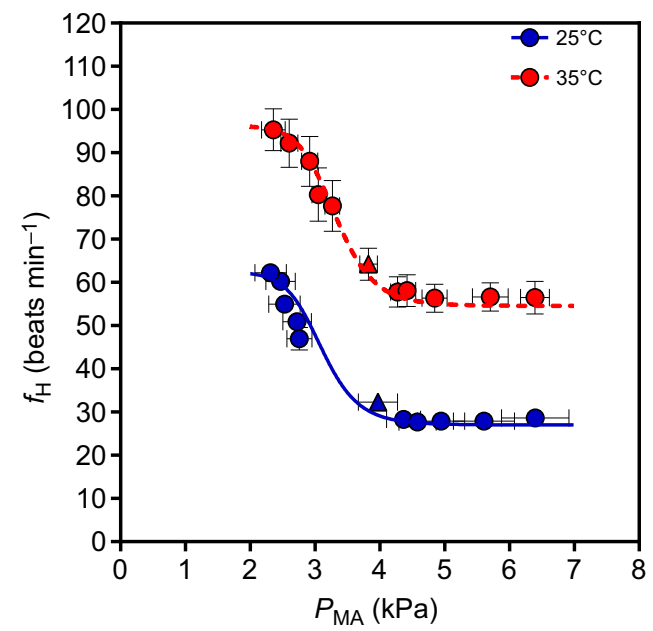

Fig. 3. Mean baroreflex relationship between $P_{\mathrm{MA}}$ and $f_{\mathrm{H}}$ in $R$. schneider at 25 and $35^{\circ} \mathrm{C}$. Curves were generated from the mean values of the curvefitted variables for each animal (see Table 1). Baseline $f_{\mathrm{H}}$ and $P_{\mathrm{MA}}$ are represented by the blue triangle at $25^{\circ} \mathrm{C}(\mathrm{N}=9)$ and the red triangle at $35^{\circ} \mathrm{C}$ $(N=9)$. For statistical values, see baroreflex variables derived from sigmoidal baroreflex- $f_{\mathrm{H}}$ curves in Table 1. 

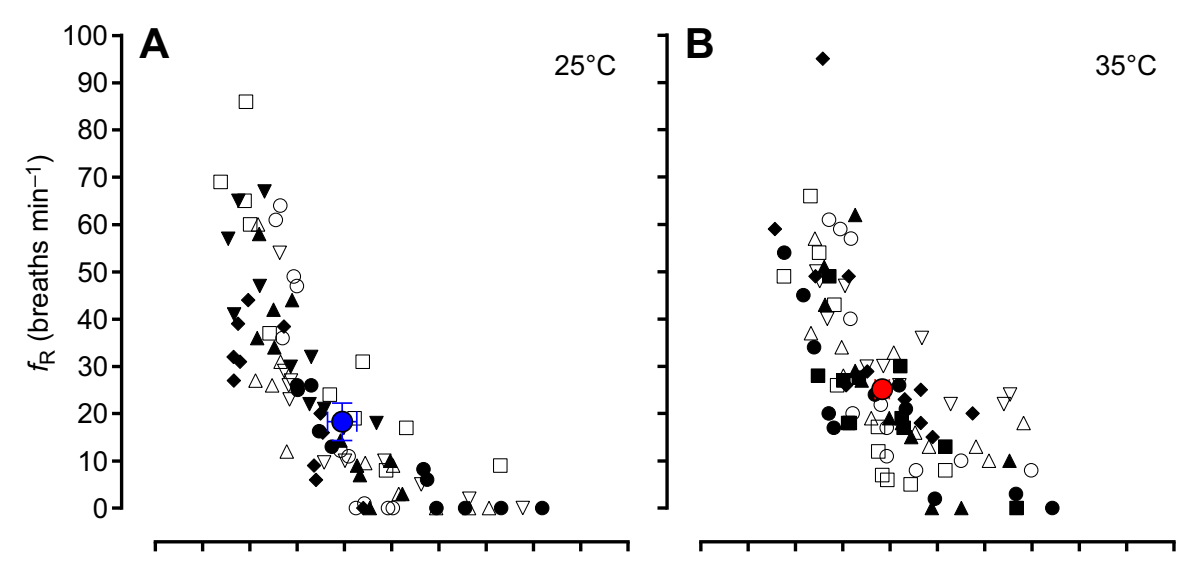

Fig. 4. The effect of changing $P_{\mathrm{MA}}$ on $f_{\mathrm{R}}, V_{\mathrm{T}}$ and $\dot{V}_{\mathrm{E}}$ in $R$. schneideri at 25 and $35^{\circ} \mathrm{C}$. $(\mathrm{A}, \mathrm{B}) f_{\mathrm{R}}$; $(\mathrm{C}, \mathrm{D}) V_{\mathrm{T}} ;(\mathrm{E}, \mathrm{F}) \dot{V}_{\mathrm{E}}$. Baseline $f_{\mathrm{R}}, V_{\mathrm{T}}, \dot{V}_{\mathrm{E}}$ and $P_{\mathrm{MA}}$ are represented by blue circles at $25^{\circ} \mathrm{C}(\mathrm{N}=8)$ and red circles at $35^{\circ} \mathrm{C}(N=8)$. Different symbols represent different animals.
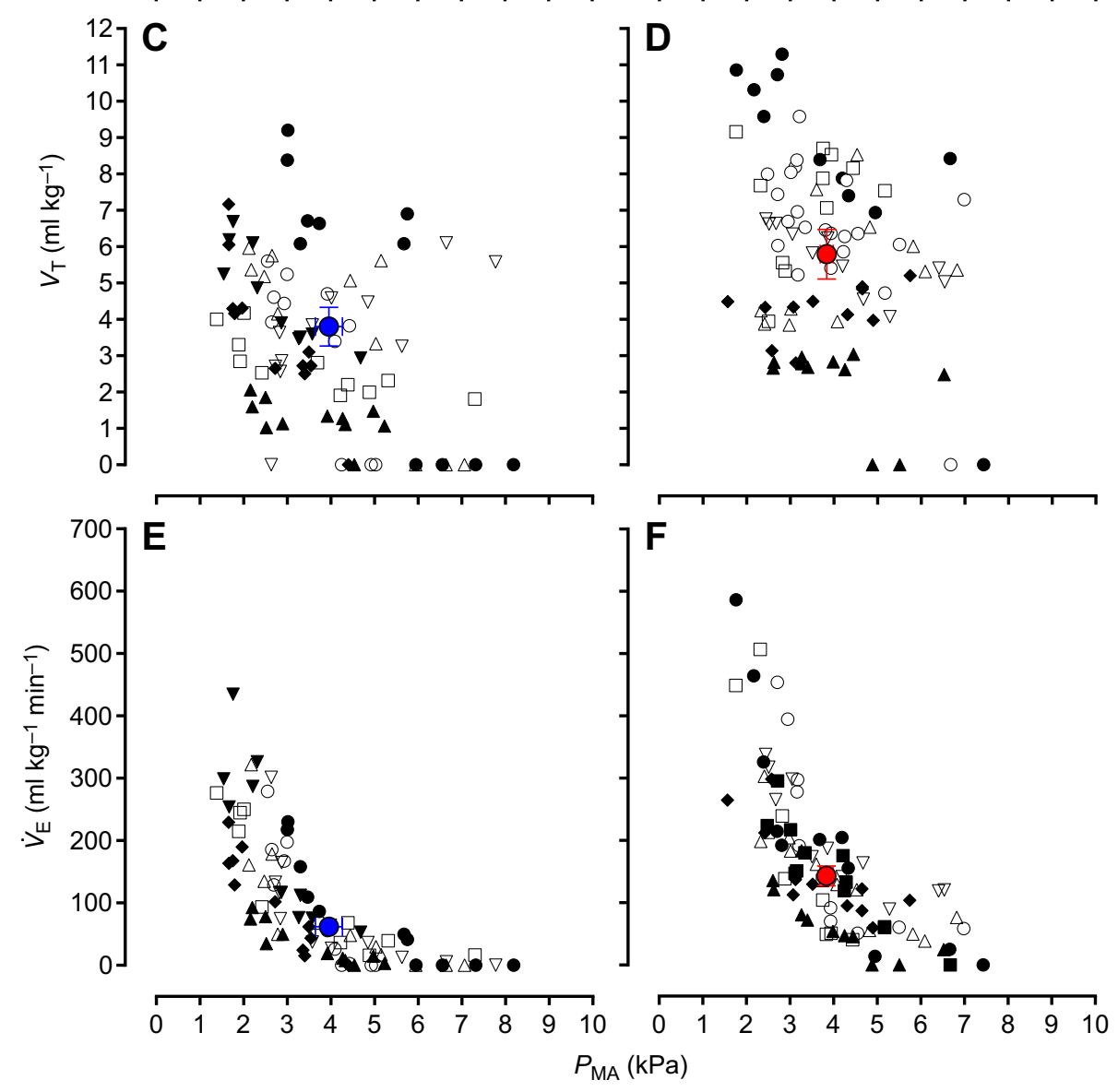

normalized as a percentage change from minimum $f_{\mathrm{H}}$ per unit change in $P_{\mathrm{MA}}(\mathrm{kPa})$, which resulted in a significant reduction of the normalized gain $(P=0.017$; Table 1$)$ at the higher temperature. In addition to temperature effects on resting $f_{\mathrm{H}}$, minimum and maximum $f_{\mathrm{H}}$ were also significantly affected by temperature $(P<0.001$; Table 1 and Fig. 3).

The effect of changing $P_{\mathrm{MA}}$ on ventilatory responses $\left(f_{\mathrm{R}}, V_{\mathrm{T}}\right.$ and $\left.\dot{V}_{\mathrm{E}}\right)$ is represented by the relationships presented in Figs 4-6. The overall variability dataset for both temperatures, showing the relationship between $P_{\mathrm{MA}}$ and $f_{\mathrm{R}}, V_{\mathrm{T}}$ or $\dot{V}_{\mathrm{E}}$, is depicted in Fig. 4. Breathing data from one representative toad are illustrated in Fig. 5, showing the slopes in $f_{\mathrm{R}} / P_{\mathrm{MA}}$ and $\dot{V}_{\mathrm{E}} / P_{\mathrm{MA}}$ during SNP-induced hypotension and $\mathrm{PE}$-induced hypertension at 25 and $35^{\circ} \mathrm{C}$; slopes were not presented for $V_{\mathrm{T}} / P_{\mathrm{MA}}$ because there was a poor relationship for most animals, as can be observed in Fig. 4C,D. The sensitivity of the response (slope) due to hypotension or hypertension was not affected by thermal changes for either $f_{\mathrm{R}} / P_{\mathrm{MA}}(P=0.84)$ or $\dot{V}_{\mathrm{E}} / P_{\mathrm{MA}}$ $(P=0.18)$ but hypotension exhibited higher average slopes for $f_{\mathrm{R}} / P_{\mathrm{MA}} \quad\left(P<0.001 ; \quad F_{1,90}=40.369\right) \quad$ and $\quad \dot{V}_{\mathrm{E}} / P_{\mathrm{MA}} \quad(P<0.001 ;$ $\left.F_{1,30}=52.764\right)$ relationships than hypertension at both temperatures (Table 2).

To test the specific responses of ventilatory variables to blood pressure changes under the two thermal conditions, the relationships between $P_{\mathrm{MA}}$ and $f_{\mathrm{R}}, V_{\mathrm{T}}$ or $\dot{V}_{\mathrm{E}}$ were examined for $P_{\mathrm{MA}}$ data binned into $1.0 \mathrm{kPa}$ intervals (Fig. 6). $f_{\mathrm{R}}$ was significantly elevated at $35^{\circ} \mathrm{C}$ for pressures higher than $4.0 \mathrm{kPa}$ only (hypertension; effect of temperature: $P<0.001 ; F_{1,175}=20.174$; Fig. 6A), while $\dot{V}_{\mathrm{E}}$ was maintained at higher values at $35^{\circ} \mathrm{C}$ across all $P_{\mathrm{MA}}$ binned ranges from hypotension to hypertension (effect of temperature: $P<0.001 ; F_{1,175}=61.694$; Fig. $6 \mathrm{C}$ ), mainly because of 

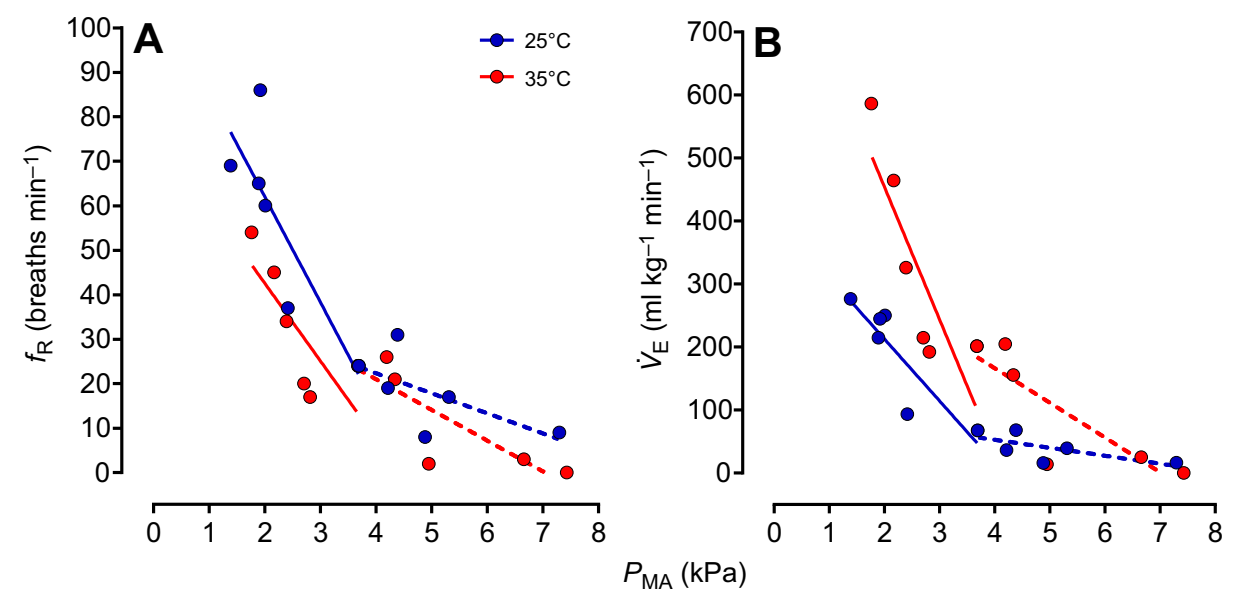

Fig. 5. Representative data from one toad for the relationship between $P_{\mathrm{MA}}$ and $f_{\mathrm{R}}$ or $\dot{V}_{\mathrm{E}}$ at 25 and $35^{\circ} \mathrm{C}$. (A) The effect of changing $P_{\mathrm{MA}}$ on $f_{\mathrm{R}}$ in the presence of SNP (continuous blue line, $25^{\circ} \mathrm{C}: r^{2}=0.70 ; P=0.04$; continuous red line, $35^{\circ} \mathrm{C}: r^{2}=0.60 ; P=0.07$ ) and $\mathrm{PE}$ (dotted blue line, $25^{\circ} \mathrm{C}: r^{2}=0.42 ; P=0.16$; dotted red line, $35^{\circ} \mathrm{C}$ : $\left.r^{2}=0.72 ; P=0.03\right)$. (B) The effect of changing $P_{\mathrm{MA}}$ on $\dot{V}_{E}$ in the presence of SNP (continuous blue line, $25^{\circ} \mathrm{C}: r^{2}=0.77 ; P=0.02$; continuous red line, $35^{\circ} \mathrm{C}: r^{2}=0.72 ; P=0.03$ ) and $\mathrm{PE}$ (dotted blue line, $25^{\circ} \mathrm{C}: r^{2}=0.47 ; P=0.13$; dotted red line, $35^{\circ} \mathrm{C}$ : $\left.r^{2}=0.72 ; P=0.03\right)$.

changes in $V_{\mathrm{T}}$ (effect of temperature: $P<0.001 ; F_{1,175}=49.823$; Fig. 6B).

\section{Effects of cholinergic and adrenergic receptor blockade on cardiorespiratory parameters}

The effect of full autonomic blockade with atropine plus sotalol on $P_{\mathrm{MA}}, f_{\mathrm{H}}$ and $\dot{V}_{\mathrm{E}}$ before and after SNP-induced hypotension in $R$. schneideri is shown in Fig. 7. Full autonomic blockade blunted the tachycardic reflex induced by hypotension (interaction of full autonomic blockade $\times$ treatment: $P<0.001 ; F_{1,22}=48.265$; Fig. 7B); in contrast, hypotension-induced increases in $\dot{V}_{\mathrm{E}}$ were not affected by full autonomic blockade $(P=0.74$; Fig. $7 \mathrm{C})$.

\section{SNP-induced hypotension effects on ventilation under normoxia and hyperoxia}

In toads exposed to hyperoxia $\left(F_{\mathrm{I}_{2}}=0.30\right)$, ventilation was significantly reduced $\left(P=0.032 ; F_{1,28}=3.177\right.$; Fig. 8$)$. Similar to animals under normoxic conditions, animals breathing $30 \% \mathrm{O}_{2}$ also expressed an increased ventilatory response $(P<0.001$; $F_{1,28}=96.581$; Fig. 8 ) after SNP-induced hypotension that did not differ from those values obtained from the group breathing normoxic gas $(P=0.6)$.

\section{DISCUSSION}

Our finding that changes in lung ventilation are driven by pressure loading and unloading in the cururu toad $R$. schneideri provides evidence of an interesting interaction among baroreceptor reflexes, pulmonary ventilation and the lymphatic system in anuran amphibians (Burggren et al., 2013; Hedrick et al., 2013). Furthermore, in contrast to previous data showing increases in baroreflex sensitivity for the thermal interval between 15 and $30^{\circ} \mathrm{C}$, an elevation in temperature to $35^{\circ} \mathrm{C}$ diminished $f_{\mathrm{H}}$ baroreflex sensitivity, but ventilatory responses to hypotension and hypertension were temperature independent.

\section{Blood pressure homeostasis in anuran amphibians}

As part of cardiovascular homeostasis in anuran amphibians, baroreceptors located in the arterial system buffer short-term blood pressure fluctuations reflexively via effectors that modulate $f_{\mathrm{H}}$ and peripheral vascular resistance. Given their high rate of lymph formation, approximately 10 times that of mammals (Desai, et al., 2010; Hillman et al., 2010), anurans have a highly efficient lymphatic system to maintain cardiovascular homeostasis. The importance of the two pairs of dorsally located lymph hearts in blood pressure homeostasis has been revealed by findings that arterial baroreceptor loading is able to reflexively decrease lymphatic $f_{\mathrm{H}}$, thereby decreasing lymph fluid return into the venous system (Yamane, 1990; Crossley and Hillman, 1999). In addition, lymph heart destruction results in a marked increase in red cell volume, interstitial edema and also death (Zwemer and Foglia, 1943; Baustian, 1988). Generated extravascular fluid in anuran amphibians returns to the cardiovascular system through a combination of changes in pressure and volume of the lymph sacs that is driven by effectors such as lung ventilation (inflation and deflation) and skeletal muscle contraction (Drewes et al., 2007; Hedrick et al., 2007). Therefore, from an evolutionary perspective, ventilatory responses that may be modulated by baroreceptor loading and unloading in $R$. schneideri can contribute to our understanding of a number of pieces of evidence for the influence of the cardiovascular system on the respiratory system in mammals (Brunner et al., 1982; Walker and Jennings, 1998; Baekey et al., 2010; McMullan and Pilowsky, 2010; Stewart et al., 2011). More interestingly, our findings add further support to a role for lung ventilation in blood pressure/volume homeostasis in anuran amphibians (Hedrick et al., 2013), although the relationship between pulmonary ventilation, baroreflex and lymphatic system in our toads is still correlational rather than mechanistic. Therefore, further studies are needed to clarify the real contribution of ventilation-driven pressure changes in lymph return.

The nucleus of the solitary tract is the major brainstem region receiving and integrating peripheral cardiovascular and respiratory afferent inputs in mammals (Lowey and Spyer, 1990). Baroreceptor afferents also converge towards the nucleus of the solitary tract in $R$. schineideri (Bianchi-da-Silva et al., 2000), but any other synaptic transmission in the CNS of amphibians related to baroreflex control is still unknown. High intensity stimulation of the recurrent laryngeal nerve, which innervates the pulmocutaneous baroreceptors, elicits cardiovascular adjustments such as bradycardia and hypotension in addition to an increased apnea period in awake $R$. marina toads (Van Vliet and West, 1986). This observation corroborates the hypertension-induced reduction in ventilation we see in our toads. Extensive overlap between respiratory and cardiovascular areas and the dose-dependent increase in pulse pressure gradually extending expiratory time in rats (in situ preparation) indicates the presence of a neural interaction between the baroreflex and respiratory patterns (Baekey et al., 2008, 2010). It is possible that anuran amphibian baroreceptor inputs into the nucleus of the solitary tract could cause suppression or release of the central respiratory drive, contributing to hypopnea and hyperpnea, respectively. Thus, relationships between blood pressure, ventilation and the lymphatic system may depend on 

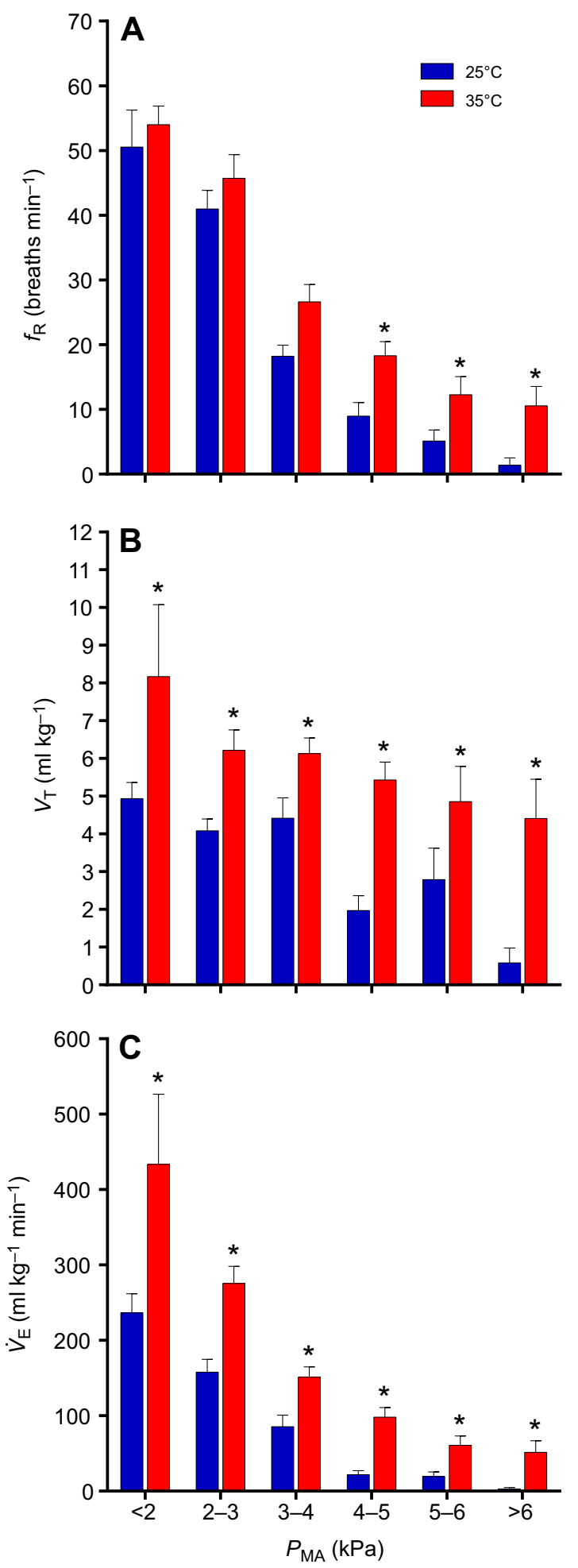

Fig. 6. Relationships between binned $P_{\mathrm{MA}}$ and $f_{\mathrm{R}}, V_{\mathrm{T}}$ or $\dot{V}_{\mathrm{E}}$ in $R$. schneideri at 25 and $35^{\circ} \mathrm{C}$. (A) $f_{\mathrm{R}} ;$ (B) $V_{\mathrm{T}} ;$ (C) $\dot{V}_{\mathrm{E}}$. $P_{\mathrm{MA}}$ was grouped into six categories covering pressures from lower than $2.0 \mathrm{kPa}$ to higher than $6.0 \mathrm{kPa}$; note that pressures between 2.0 and $6.0 \mathrm{kPa}$ were binned into $1.0 \mathrm{kPa}$ intervals.

*Significant effect of temperature within binned $P_{\text {MA }}$ interval (two-way ANOVA; $P<0.05$; Holm-Šídák's post hoc test).

integrated information in the CNS; however, whether these circuits exist and/or are interacting with each other remains to be further investigated in amphibians.
One may argue that the respiratory response to hypotension results from peripheral chemoreflex activation, but evidence does not support this hypothesis. In toads, we know that the hypoxic ventilatory response is mediated by reductions in arterial partial pressure of oxygen $\left(\mathrm{Pa}_{\mathrm{O}_{2}}\right)$ (Wang et al., 1994; Branco and Glass, 1995). In this context, the discharge frequency of the carotid chemoreceptors in $R$. marina did not increase until $\mathrm{Pa}_{\mathrm{O}_{2}}$ fell between 5.3 and $8.0 \mathrm{kPa}(40-60 \mathrm{~mm} \mathrm{Hg})$, and remained silenced in hyperoxic gas conditions $\left(30 \% \mathrm{O}_{2}\right.$ in inspired air; Van Vliet and West, 1992). In our animals, an increased $F_{\mathrm{I}_{\mathrm{O}_{2}}}(0.30)$ in the air decreased baseline $\dot{V}_{\mathrm{E}}$ and did not abolish the ventilatory response to hypotension (Fig. 8), suggesting little to no involvement of these chemoreceptors. In addition, hypoxic ventilatory responses in $R$. schneideri, in order to improve lung gas exchange, are mediated by altering $V_{\mathrm{T}}$ rather than $f_{\mathrm{R}}$ (Bícego-Nahas et al., 2001; Gargaglioni and Branco, 2001, 2003), while increases in ventilation elicited by hypotension in the present study were achieved through increases in $f_{\mathrm{R}}$ rather than $V_{\mathrm{T}}$ (Fig. 2). We also know that, at least in $R$. marina, carotid labyrinth chemoreceptors are not flow sensitive; afferent nerve activity is not affected by carotid labyrinth blood supply cessation, and the hypoxia stimulus is no longer effective in stimulating chemoreceptors in these conditions (Van Vliet and West, 1992). Thus, our data suggest that ventilatory responses during acute hypotension may instead be a consequence of baroreceptors influencing respiratory areas. Further support for this view comes from our results with hypertension, which induced the opposite response, i.e. ventilation decrease.

\section{Temperature effects on cardiorespiratory reflex responses}

In the present study, increasing the temperature to $35^{\circ} \mathrm{C}$ promoted cardiovascular and respiratory adjustments such as increases in baseline $f_{\mathrm{H}}$ and $\dot{V}_{\mathrm{E}} \cdot \dot{V}_{\mathrm{E}}$ was affected by temperature from 25 to $35^{\circ} \mathrm{C}$ (127\% increase, $\left.Q_{10}=2.27\right)$, mainly as a result of increases in $V_{\mathrm{T}}$ $\left(Q_{10}=1.57\right)$. Thus, increased $\dot{V}_{\mathrm{E}}$ at high temperature matches an elevated metabolic rate up to $105 \%$ (thermal interval range from 25 to $35^{\circ} \mathrm{C}$ ) reported in a closely related species, $R$. marina (Overgaard et al., 2012). High temperature exposure $\left(35^{\circ} \mathrm{C}\right)$ in $R$. schneideri elicited cardiovascular adjustments to support an increased metabolic demand in which baseline $f_{\mathrm{H}}$ rose $100 \%$ relative to that at $25^{\circ} \mathrm{C}$, while blood pressure remained unchanged. Sustaining blood pressure relatively constant, for the thermal interval between 25 and $35^{\circ} \mathrm{C}$, while resting $f_{\mathrm{H}}$ increased accordingly, likely reflects a general peripheral vasodilation (Zena et al., 2015), as stroke volume remains fairly constant (Hedrick et al., 1999).

Pharmacologically induced changes in blood pressure not only triggered baroreflex responses in $f_{\mathrm{H}}$ but also affected $\dot{V}_{\mathrm{E}}$ in $R$. schneideri, similar to what has been reported for mammals (Brunner et al., 1982; Walker and Jennings, 1998; McMullan and Pilowsky, 2010; Stewart et al., 2011). Increases in blood pressure in the toads were followed by reductions in $\dot{V}_{\mathrm{E}}$, primarily through modification of $f_{\mathrm{R}}$ and to a lesser extent $V_{\mathrm{T}}$; conversely, $\dot{V}_{\mathrm{E}}$ was significantly increased during hypotension. In contrast to decreases in $V_{\mathrm{T}}$ during hypertension at $25^{\circ} \mathrm{C}$ (higher doses of $\mathrm{PE}$ ), hypertension at $35^{\circ} \mathrm{C}$ was unable to decrease $V_{\mathrm{T}}$, despite diminished $f_{\mathrm{R}}$. In addition, the relationship between $P_{\mathrm{MA}}$ and the ventilatory responses (binned $P_{\mathrm{MA}}$ data; Fig. 6) revealed that at high temperature, toads exhibit elevated ventilation throughout the entire $P_{\mathrm{MA}}$ range $(<2$ to $>6 \mathrm{kPa})$, mainly because of increased $V_{\mathrm{T}}$. This permits the toads to keep an elevated ventilatory airflow in their lungs, ensuring sufficient gas exchange at the organ level during high metabolic demand, while their ability to change ventilation in response to baroreceptor loading and unloading is preserved 
Table 2. Regression analysis slopes for the relationships between $P_{\mathrm{MA}}$ and $f_{\mathrm{R}}$ or $\dot{V}_{\mathrm{E}}$ generated after serial bolus injections of phenylephrine (hypertension) and sodium nitroprusside (hypotension) at 25 and $35^{\circ} \mathrm{C}$ in the toad $R$. schneideri

\begin{tabular}{lllllll}
\hline & \multicolumn{2}{c}{$f_{\mathrm{R}}$ slope $\left(\right.$ breaths $\left.\mathrm{min}^{-1} \mathrm{kPa}^{-1}\right)$} & & \multicolumn{2}{c}{$\dot{V}_{\mathrm{E}}$ slope $\left(\mathrm{ml} \mathrm{kg}^{-1} \mathrm{~min}^{-1} \mathrm{kPa}^{-1}\right)$} \\
\cline { 2 - 3 } Temperature $\left({ }^{\circ} \mathrm{C}\right)$ & Hypotension & Hypertension & & $P$ & Hypotension & Hypertension \\
\hline 25 & $-16.8 \pm 4.8$ & $-7.1 \pm 2.1$ & $<0.001^{*}$ & $-97.6 \pm 17.1$ & $-23.6 \pm 6.0$ \\
35 & $-19.8 \pm 3.0$ & $-4.8 \pm 0.7$ & $<0.001^{*}$ & $-141.0 \pm 29.5$ & $-28.7 \pm 6.4$ & $<0.001^{*}$ \\
\hline
\end{tabular}

*Significant difference between hypotension and hypertension slopes (Student's $t$-test) within each temperature. $f_{\mathrm{R}}$ slope, slope relationship between $f_{\mathrm{R}}$ and $P_{\mathrm{MA}}$; $\dot{V}_{\mathrm{E}}$ slope, slope relationship between $\dot{V}_{\mathrm{E}}$ and $P_{\mathrm{MA}} . N=8$.

(Table 2 and Fig. 5). In agreement with the ability of anurans to respond to hypotension primarily by increasing $f_{\mathrm{H}}$ (Hedrick et al., 2015; Zena et al., 2015), R. schneideri also exhibited a prominent ventilatory response to reductions rather than increases in blood pressure. This provides correlational data for the ability of anurans to use their lungs to regulate blood volume (Hedrick et al., 2013); in addition, it contributes to a prevailing view that amphibians strongly
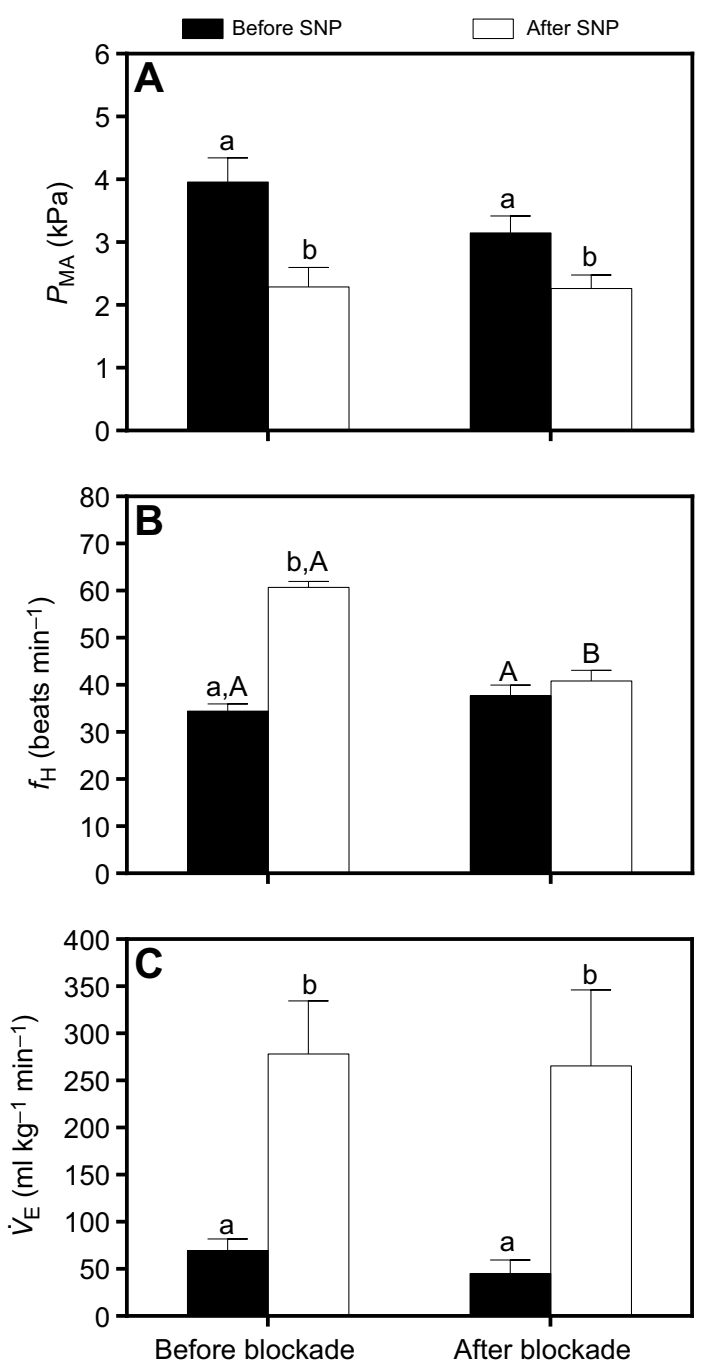

Fig. 7. Effect of SNP on $P_{\mathrm{MA}}, f_{\mathrm{H}}$ and $\dot{V}_{\mathrm{E}}$ in $R$. schneideri before and after full autonomic blockade with atropine and sotalol. Changes in $P_{\mathrm{MA}}(\mathrm{A}), f_{\mathrm{H}}(\mathrm{B})$ and $\dot{V}_{E}(C)$ induced by SNP $\left(100 \mu \mathrm{gg}^{-1}\right)$ before $(N=7)$ and after $(N=5)$ full autonomic blockade with atropine $\left(3.0 \mathrm{mg} \mathrm{kg}^{-1}\right)$ plus sotalol $\left(3.0 \mathrm{mg} \mathrm{kg}^{-1}\right)$ at $25^{\circ} \mathrm{C}$. Different lowercase letters indicate a significant effect of SNP injections; different uppercase letters indicate a significant effect of full autonomic blockade before or after SNP (two-way repeated measures ANOVA; $P<0.05$; Holm-Šídák's post hoc test). defend short-term blood pressure imbalances against low pressure events (Hedrick et al., 2015; Zena et al., 2015).

Beyond temperature-independent sensitivity of the ventilatory reflex response, the baroreflex of $f_{\mathrm{H}}$ in our toads in fact diminished at $35^{\circ} \mathrm{C}$, as seen by the normalized gain (Table 1). This suggests that the cardiac limb of the baroreflex response is possibly approaching its thermal limit. In a previous study (Zena et al., 2015), we showed that $f_{\mathrm{H}}$ baroreflex sensitivity is enhanced by temperature for a thermal interval between 15 and $30^{\circ} \mathrm{C}$. Nevertheless, our data seem to indicate that further increases in temperature (above $30^{\circ} \mathrm{C}$ ), instead of improving $f_{\mathrm{H}}$ baroreflex sensitivity, actually reduce it in our toads. A possible explanation for this may involve a thermal impairment of the tachycardic response to hypotension. This is indicated by a lower $Q_{10}$ effect (1.5) for the maximum $f_{\mathrm{H}}$ response achieved for the highest dose of SNP. Baseline $f_{\mathrm{H}}$ was profoundly affected by temperature, shifting the operating point of the baroreflex upward $\left(100 \%\right.$ increase) with a $Q_{10}$ effect of 2.0. Hence, in order to sustain $f_{\mathrm{H}}$ baroreflex sensitivity from 25 to $35^{\circ} \mathrm{C}$, we expected that temperature would affect maximum and minimum $f_{\mathrm{H}}$ responses through the same $Q_{10}$ effect as baseline $f_{\mathrm{H}}$; however, this was not the case for maximum $f_{\mathrm{H}}$.

The ability to mount reflex $f_{\mathrm{H}}$ responses mainly to hypotension in anurans accounts for most of the $f_{\mathrm{H}}$ reflex responses due to changes in blood pressure (Hedrick et al., 2015; Zena et al., 2015) and can be strongly affected by the inability to further increase $f_{\mathrm{H}}$ when the animal has an already elevated baseline value. Such a situation can be encountered by the animal at very high temperatures $\left(>35^{\circ} \mathrm{C}\right.$; Overgaard et al., 2012) or during enforced activity (Wahlqvist and Campbell, 1988); the latter is already known to reset the baroreflex to higher $f_{\mathrm{H}}$ and $P_{\mathrm{MA}}$ values in humans (Norton et al., 1999).

Overall it seems that anurans rely on a combination of mechanisms to maintain cardiovascular homeostasis. The baroreflex in anurans is clearly linked to the lymphatic system because lymph hearts are

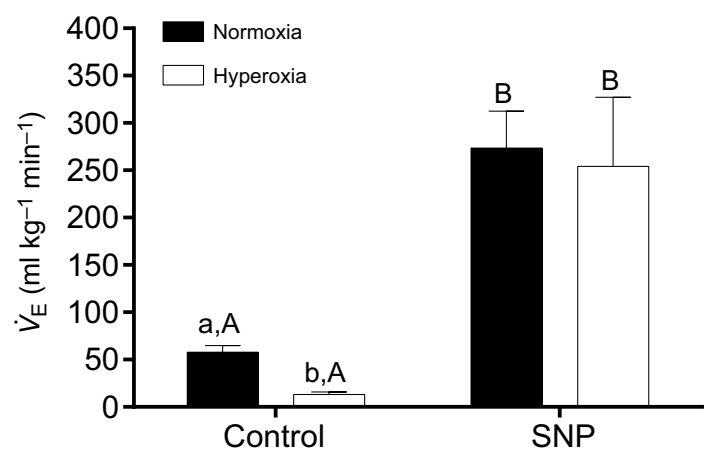

Fig. 8. Effect of SNP-induced hypotension on $\dot{V}_{\mathrm{E}}$ in $\boldsymbol{R}$. schneideri under normoxia and hyperoxia. Different lowercase letters indicate a significant difference between normoxia and $30 \%$ hyperoxia; different uppercase letters indicate a significant difference between control and SNP injection within each gas condition (two-way repeated measures ANOVA; $P<0.05$; Holm-Šídák's post hoc test). Normoxia, $N=10$; hyperoxia, $N=5$. 
under feedback control of arterial baroreceptors (Crossley and Hillman, 1999) and pulmonary ventilation works as an efficient effector for lymph mobilization (Hedrick et al., 2007). Based on our data, short-term imbalances in blood pressure are defended by mechanisms that involve reflex $f_{\mathrm{H}}$ adjustments along with changes in pulmonary ventilation (mainly breathing frequency) that may essentially arise from afferent integration of baroreceptors in the CNS, modulating respiratory areas, as proposed for mammals (McMullan and Pilowsky, 2010). Furthermore, high environmental temperatures decrease the $f_{\mathrm{H}}$ baroreflex by impairing maximum $f_{\mathrm{H}}$ response effectiveness (lower $Q_{10}$ ) when baseline $f_{\mathrm{H}}$ is already elevated, while the ventilatory component of this response is preserved. Although the loop between ventilation and lymph flow based on baroreflex regulation deserves further experimentation, our present findings in $R$. schneideri clearly provide a correlational link among the baroreflex, lung ventilation and the lymphatic system in anurans, in addition to providing evolutionary insights for better understanding of the links between blood pressure and ventilation in mammals. Among amphibians, however, whether the role of lung ventilation is a conserved feature contributing to blood pressure homeostasis is still unknown, as some lungless amphibians like salamanders (Hutchison, 2008) and the Bornean flat-headed frog, Barbourula kalmantanensis (Bickford et al., 2008), may rely on other effectors for vertical lymph movement (i.e. skeletal muscle contraction; Drewes et al., 2007), and thus blood pressure/volume regulation dependent on ventilation certainly does not exist.

\section{Acknowledgements}

We thank Dr Lynn Hartzler who kindly reviewed our manuscript for English grammar and $\mathrm{Dr}$ Brent Foy for his contributions to our statistical analysis of $P_{\mathrm{MA}}$ and ventilatory response relationships. We are grateful to Mr Wagner Bianchini for allowing us to access his aquatic plants farm for toad collection.

\section{Competing interests}

The authors declare no competing or financial interests.

\section{Author contributions}

L.A.Z. conceived, designed and performed the experiments, and analyzed the data; L.A.Z., G.S.F.d.S., L.H.G. and K.C.B. interpreted the data; L.A.Z., K.C.B., G.S.F.d.S. and L.H.G wrote the manuscript.

\section{Funding}

The present study was supported by the Fundação de Amparo à Pesquisa do Estado de São Paulo-FAPESP [08/57712-4 (INCTFisiologia Comparada); 2012/ 17379-0; 2nd year PhD fellowship to L.A.Z.] and Coordenação de Aperfeiçoamento de Pessoal de Nível Superior (CAPES; 1 st year PhD fellowship to L.A.Z.). This study was part of the activities developed by L.A.Z. during his $\mathrm{PhD}$ at the Joint Graduate Program in Physiological Sciences (PIPGCF) from UFSCar/UNESP and was presented at the Experimental Biology meeting April 2016 (FAPESP-Brazil 2012/ $17379-0$ and APS-USA).

\section{References}

Altimiras, J., Franklin, C. E. and Axelsson, M. (1998). Relationships between blood pressure and heart rate in the saltwater crocodile Crocodylus porosus. J. Exp. Biol. 2242, 2235-2242.

Baekey, D. M., Dick, T. E. and Paton, J. F. R. (2008). Pontomedullary transection attenuates central respiratory modulation of sympathetic discharge, heart rate and the baroreceptor reflex in the in situ rat preparation. Exp. Physiol. 93, 803-816.

Baekey, D. M., Molkov, Y. I., Paton, J. F. R., Rybak, I. A. and Dick, T. E. (2010). Effect of baroreceptor stimulation on the respiratory pattern: Insights into respiratory-sympathetic interactions. Respir. Physiol. Neurobiol. 174, 135-145.

Baustian, M. (1988). The contribution of lymphatic pathways during recovery from hemorrhage in the toad Bufo marinus. Physiol. Zool. 61, 555-563.

Bianchi-da-Silva, L. M., Menescal-de-Oliveira, L. and Hoffmann, A. (2000). Baroreceptor control of heart rate in the awake toad: peripheral autonomic effectors and arterial baroreceptor areas. J. Auton. Nerv. Syst. 80, 31-39.

Bícego-Nahas, K. C., Gargaglioni, L. H. and Branco, L. G. S. (2001). Seasonal changes in the preferred body temperature, cardiovascular, and respiratory responses to hypoxia in the toad, Bufo paracnemis. J. Exp. Zool. 289, 359-365.
Bickford, D., Iskandar, D. and Barlian, A. (2008). A lungless frog discovered on Borneo. Curr. Biol. 18, R374-R375.

Branco, L. G. and Glass, M. L. (1995). Ventilatory responses to carboxyhaemoglobinaemia and hypoxic hypoxia in Bufo paracnemis. J. Exp. Biol. 198, 1417-1421.

Brunner, M. J., Sussman, M. S., Greene, A. S., Kallman, C. H. and Shoukas, A. A. (1982). Carotid sinus baroreceptor reflex control of respiration. Circ. Res. 51, 624-636.

Burggren, W. W., Christoffels, V. M., Crossley, D. A., Enok, S., Farrell, A., Hedrick, M. S., Hicks, J. W., Jensen, B., Moorman, A. F. M., Mueller, C. A. et al. (2013). Comparative cardiovascular physiology: future trends, opportunities and challenges. Acta Physiol. 1987, 257-276.

Crossley, D. A., II and Hillman, S. S. (1999). The role of pulmocutaneous baroreceptors in the control of lymphatic heart rate in the toad Bufo marinus. Physiol. Biochem. Zool. 72, 109-115.

Desai, P., Williams, A. G., Jr., Prajapati, P. and Downey, H. F. (2010). Lymph flow in instrumented dogs varies with exercise intensity. Lymphat. Res. Biol. 8, 143-148.

Drewes, R. C., Hedrick, M. S., Hillman, S. S. and Withers, P. C. (2007). Unique role of skeletal muscle contraction in vertical lymph movement in anurans. J. Exp. Biol. 210, 3931-3939.

Gargaglioni, L. H. and Branco, L. G. (2001). Effect of nitric oxide in the nucleus isthmi on the hypoxic and hypercarbic drive to breathing of toads. Am. J. Physiol. Regul. Integr. Comp. Physiol. 281, R338-R345.

Gargaglioni, L. H. and Branco, L. G. S. (2003). Role of glutamate in the nucleus isthmi on the hypoxia- and hypercarbia-induced hyperventilation of toads. Respir. Physiol. Neurobiol. 135, 47-58.

Gentz, E. J. (2007). Medicine and surgery of amphibians. ILAR J. 48, 255-259.

Glass, M. L., Wood, S. C. and Johansen, K. (1978). The application of pneumotachography on small unrestrained animals. Comp. Biochem. Physiol. A Physiol. 59, 425-427.

Glass, M. L., Fernandes, M. S., Soncini, R., Glass, H. and Wasser, J. S. (1997). Effects of dry season dormancy on oxygen uptake, heart rate, and blood pressures in the toad, Bufo paracnemis. J. Exp. Zool. 279, 330-336.

Guerra, A. R. G., Gargaglioni, L. H., Noronha-De-Souza, C. R., Abe, A. S., Branco, L. G. S. and Bícego, K. C. (2008). Role of central nitric oxide in behavioral thermoregulation of toads during hypoxia. Physiol. Behav. 95, 101-107.

Hedrick, M. S., Palioca, W. B. and Hillman, S. S. (1999). Effects of temperature and physical activity on blood flow shunts and intracardiac mixing in the toad Bufo marinus. Physiol. Biochem. Zool. 72, 509-519.

Hedrick, M. S., Drewes, R. C., Hillman, S. S. and Withers, P. C. (2007). Lung ventilation contributes to vertical lymph movement in anurans. J. Exp. Biol. 210 3940-3945.

Hedrick, M. S., Hillman, S. S., Drewes, R. C. and Withers, P. C. (2013). Lymphatic regulation in nonmammalian vertebrates. J. Appl. Physiol. 115, 297-308.

Hedrick, M. S., McNew, K. A. and Crossley, D. A. (2015). Baroreflex function in anurans from different environments. Comp. Biochem. Physiol. A Mol. Integr. Physiol. 179, 144-148.

Hillman, S. S., Withers, P. C., Drewes, R. C. and Hillyard, S. D. (2009). Ecological and Environmental Physiology of Amphibians. Oxford: Oxford University Press.

Hillman, S. S., Hedrick, M. S., Drewes, R. C. and Withers, P. C. (2010). Lymph flux rates from various lymph sacs in the cane toad Rhinella marina: an experimental evaluation of the roles of compliance, skeletal muscles and the lungs in the movement of lymph. J. Exp. Biol. 213, 3161-3166.

Hutchison, V. H. (2008). Amphibians: lungs' lift lost. Curr. Biol. 18, R392-R393.

Jared, C., Antoniazzi, M. M., Jordão, A. E. C., Silva, J. R. M. C., Greven, H. and Rodrigues, M. T. (2009). Parotoid macroglands in toad (Rhinella jimi): Their structure and functioning in passive defence. Toxicon 54, 197-207.

Lowey, A. D. and Spyer, K. M. (1990). Central Regulation of Autonomic Functions. New York, NY: Oxford University Press.

McMullan, S. and Pilowsky, P. M. (2010). The effects of baroreceptor stimulation on central respiratory drive: a review. Respir. Physiol. Neurobiol. 174, 37-42.

Moreira, L. a., Fenolio, D. B., Silva, H. L. R. and Silva, N. J. Jr. (2009). A preliminary list of the herpetofauna from termite mounds of the cerrado in the upper Tocantins river valley. Pap. Avulsos Zool. 49, 183-189.

Noronha-de-Souza, C. R., Bovo, R. P., Gargaglioni, L. H., Andrade, D. V. and Bícego, K. C. (2015). Thermal biology of the toad Rhinella schneideri in a seminatural environment in southeastern Brazil. Temperature 2, 554-562.

Norton, K. H., Boushel, R., Strange, S., Saltin, B. and Raven, P. B. (1999). Resetting of the carotid arterial baroreflex during dynamic exercise in humans. J. Appl. Physiol. 87, 332-338.

Overgaard, J., Andersen, J. L., Findsen, A., Pedersen, P. B. M., Hansen, K. Ozolina, K. and Wang, T. (2012). Aerobic scope and cardiovascular oxygen transport is not compromised at high temperatures in the toad Rhinella marina. J. Exp. Biol. 215, 3519-3526.

Reid, I. A. (1996). Angiotensin II and baroreflex control of heart rate. News Physiol. Sci. 11, 270-274

Reyes, C., Fong, A. Y., Brink, D. L. and Milsom, W. K. (2014). Distribution and innervation of putative arterial chemoreceptors in the bullfrog (Rana catesbeiana). J. Comp. Neurol. 522, 3754-3774. 
Sandblom, E. and Axelsson, M. (2005). Baroreflex mediated control of heart rate and vascular capacitance in trout. J. Exp. Biol. 208, 821-829.

Smith, S. A. (2007). Compendium of drugs and compounds used in amphibians. ILAR J. 48, 297-300.

Stewart, J. M., Rivera, E., Clarke, D. A., Baugham, I. L., Ocon, A. J., Taneja, I., Terilli, C. and Medow, M. S. (2011). Ventilatory baroreflex sensitivity in humans is not modulated by chemoreflex activation. Am. J. Physiol. Heart Circ. Physiol. 300 , $\mathrm{H} 1492-\mathrm{H} 1500$.

Van Vliet, B. N. and West, N. H. (1986). Cardiovascular responses to electrical stimulation of the recurrent laryngeal nerve in conscious toads. J. Comp. Physiol. B 156, 363-375.

Van Vliet, B. N. and West, N. H. (1992). Functional characteristics of arterial chemoreceptors in an amphibian (Bufo marinus). Respir. Physiol. 88 113-127.

Wahlqvist, B. Y. I. and Campbell, G. (1988). Autonomic influences on heart rate and blood pressure in the toad, Bufo marinus, at rest and during exercise. J. Exp. Biol. 134, 377-396.
Walker, J. K. L. and Jennings, D. B. (1998). Respiratory effects of pressor and depressor agents in conscious rats. Can. J. Physiol. Pharmacol. 76, 707-714.

Wang, T., Branco, L. G. and Glass, M. L. (1994). Ventilatory responses to hypoxia in the toad Bufo paracnemis before and after a decrease in haemoglobin oxygencarrying capacity. J. Exp. Biol. 186, 1-8.

Yamane, M. (1990). The arterial baroreceptor-lymph heart inhibitory reflex and its pathway in the bullfrog Rana catesbeiana. Kawasaki Med. J. 16, 93-100.

Zena, L. A., Gargaglioni, L. H. and Bícego, K. C. (2015). Temperature effects on baroreflex control of heart rate in the toad, Rhinella schneideri. Comp. Biochem. Physiol. A Mol. Integr. Physiol. 179, 81-88.

Zena, L. A., Dantonio, V., Gargaglioni, L. H., Andrade, D. V., Abe, A. S. and Bícego, K. C. (2016). Winter metabolic depression does not change arterial baroreflex control of heart rate in the tegu lizard Salvator merianae. J. Exp. Biol. 219, 725-733.

Zwemer, R. and Foglia, V. (1943). Fatal loss of plasma volume after lymph heart destruction in toads. Exp. Biol. Med. 53, 14-17. 